\title{
TREE AND SHRUB DIVERSITY IN AGROFORESTRY HOMEGARDENS IN RURAL COMMUNITY IN EASTERN AMAZON
}

\author{
Bruna Naiara Rocha Garcia ${ }^{1}$, Thiago Almeida Vieira ${ }^{2 *}$, Francisco de Assis Oliveira ${ }^{3}$ \\ ${ }^{1}$ Federal University of Western Pará, Postgraduate Programme in Society, Nature and Development, Santarém, Pará, Brazil - \\ brunanaiara26@hotmail.com \\ $2^{2 *}$ Federal University of Western Pará, Professor of Postgraduate Programme in Society, Environment and Quality of Life, Santarém, Pará, Brazil - \\ thiago.vieira@ufopa.edu.br \\ ${ }^{3}$ Amazon Federal Rural University, Professor of Postgraduate Programme in Forest Sciences, Belém, Pará, Brazil - \\ francisco.oliveira@ufra.edu.br
}

Recebido para publicação: 22/08/2016 - Aceito para publicação:05/10/2017

\begin{abstract}
This article described and analyzed the tree and shrub species composition of homegardens in a rural community in Eastern Amazon, Brazil. Data were collected from 30 homegardens stratified into two groups of 15: homegardens of northeastern and homegardens of peasants from South Brazil, based on floristic surveys of 100\% of the tree and shrub components. We studied the floristic composition and the preference value index (PVI), and classified the homegardens by cluster analysis. In the evaluated homegardens, 2270 vegetable plants of 67 species, 53 genera and 28 botanical families were recorded. The most representative families, according to the number of species, were Arecaceae, Rutaceae, Myrtaceae, Annonaceae, and Caesalpiniaceae. Cocos nucifera (coconut) had the highest PVI (97.37), followed by banana, orange, peach palm and avocado, confirming the preference for fruit species with commercial value. The floristic composition of homegardens revealed that coconut is the most commonly cultivated species. The species diversity in the homegardens was moderate, and evenness was considered medium, despite the dominance of species such as banana and açaí palm. The origin of the farmers did not influence the similarity among homegardens, but it influenced vegetal species richness, diversity and density, which were higher in the southerners' homegardens.

Keywords: Floristic composition; family agriculture; agroforestry diversity.
\end{abstract}

Resumo
Biodiversidade de espécies arbóreas e arbustivas em quintais agroflorestais em comunidade rural na Amazônia Oriental: Este artigo descreveu e analisou a composição florística dos estratos arbóreos e arbustivos de quintais agroflorestais de uma comunidade rural na Amazônia Oriental, Brasil. Os dados foram coletados a partir de 30 quintais, estratificados em dois grupos de 15: quintais manejados por agricultores provenientes do nordeste brasileiro e por oriundos da região sul do Brasil, com base em levantamentos florísticos de $100 \%$ dos componentes de árvores e arbustos. Estudou-se a composição florística e o índice de preferência valor (IVP), e classificou-se os quintais por meio de análise de cluster. Nos quintais avaliados, foram registrados 2270 indivíduos pertencentes a 67 espécies, 53 gêneros e 28 famílias botânicas. As famílias mais representativas, de acordo com o número de espécies, foram: Arecaceae, Rutaceae, Myrtaceae, Annonaceae e Caesalpiniaceae. Cocos nucifera (coco) teve o maior IVP $(97,37)$, seguido pela banana, laranja, pupunha e abacate, indicando preferência por espécies de frutas com valor comercial. A composição florística revelou que o coco é a espécie mais cultivada. A diversidade de espécies nos quintais foi moderada, e a riqueza, considerada média, apesar da dominância de espécies, como banana e açaí. A origem dos agricultores não influenciou na semelhança entre quintais, mas influenciou na riqueza, densidade e diversidade de espécies vegetais, sendo maiores nos quintais manejados por agricultores oriundos da região sul do Brasil.

Palavras-chave: Composição florística; agricultura familiar; diversidade agroflorestal.

\section{INTRODUCTION}

The biological conservation and management of traditional land use systems, as of homegardens for example, have gained recognition, since the daily practices related to this tradition have contributed to the preservation of landscape and local culture in several areas of exploitation (COSTA et al., 2002). In this context, agroforestry homegardens, frequent in family farming, have been acknowledged as a safeguard of environmental conservation. In

FLOREST A, Curitiba, PR, v. 47, n. 4, p. 543 - 552, out/dez. 2017

Garvia, B. N. R. et al.

ISSN eletrônico 1982-4688

DOI: $10.5380 /$ rf.v47i4.48196 
addition, these production systems can lead to an integration between different areas in rural environments, optimize the rational use of natural resources, and contribute to the conservation of traditional knowledge.

In general, the species introduced in homegardens are related to the geographical origin of the farmers and their culture, which contributes to the species diversity. The knowledge of the farmer regarding floristic composition is a strong ally to diagnose the richness of the homegarden species and it manages them to ensure food security and possibly earn an additional family income (VIEIRA et al., 2012).

Nevertheless, in recent decades, rural areas in the State of Pará have undergone great changes, whether by accelerated urbanization or by the advance of modern agriculture into areas historically occupied by traditional populations. It leads to the loss of agrobiodiversity and abandonment of the agricultural systems created and maintained by farmers over generations (AMOROZO, 2008).

In spite of the agricultural advancement, particularly monoculture, into native forest areas, subsistence agriculture - that includes several systems of traditional land use, such as agroforestry homegardens - still persists and represents a major source of social reproduction of many rural families.

Thus, homegardens should be studied in order to discover how these agro-ecosystems are managed in subsistence farming, provided that the intellectual property of the farmers is preserved. Therefore, the purpose of this study was to describe and analyze the tree and shrub species composition of homegardens in a rural community in Santarém, Pará, Brazil.

\section{MATERIAL AND METHODS}

\section{Study area}

The study was carried out in the rural community of Boa Esperança, municipality of Santarem, $43 \mathrm{~km}$ away from the center and along the roadside of the PA 370 Rodovia Santarém Curuá-Una, in the western region of Pará (latitude $02^{\circ} 25^{\prime} 30^{\prime \prime} \mathrm{S}$ and longitude $54^{\circ} 42^{\prime} 50^{\prime \prime} \mathrm{W}$ ) (IDESP, 2013). This community is an important center of tapioca flour production of Santarém, Pará, and it is characterized by a high population share of farmers from northeastern and southern Brazil.

\section{Selection of the homegardens}

The homegardens were selected due to their apparent diversity, i.e., identification of the yards with greatest diversity, based on visual observations (COSTANTIN; VIEIRA, 2005). The 30 selected homegardens were stratified into two owner groups: 15 homegardens managed by farmers from northeastern Brazil and 15, from the south of Brazil. 25\% of the farmers in this community are registered producers of the cooperative of family farming of Boa Esperança. In order to compare the floristic composition of the homegardens, the results of diversity, evenness and species richness were analyzed separately.

\section{Data collection and analysis}

Direct observations, photographic records and a floristic inventory of all selected areas applied in theproperties were used to collect data. The floristic composition of the systems was identified through a floristic inventory of $100 \%$ of the tree and shrub species of the productive homegardens (VIEIRA et al., 2012).

The taxa were identified based on prior knowledge of the field staff, as well as by means of photographic records and literature searches. Thus, species under doubtful identification by the researcher were separated in order to ask the owner their popular name and/or the possibility of collecting fertile material for comparison with herbarium specimen (SEMEDO; BARBOSA, 2007), or to be identified by specialists of the Federal University of Western Pará.

The floristic composition of the gardens was studied for species richness and floristic diversity, according to the Shannon Index (H') (MAGURRAN, 1988):

$$
\mathrm{H}^{\prime}=-\Sigma p i \ln p i,
$$

in which: pi is the ratio of the number of plants of a species (ni) by the total number of sampled plants $(\mathrm{N})$.

The evenness was measured by the evenness index (Pielou index, J), which allows the representation of the uniformity distribution of plants among all species.

$$
\mathrm{J}=\mathrm{H}^{\prime} / \mathrm{H}^{\prime} \max
$$

in which: H' is the Shannon Index and H'max the Neperian logarithm of the number of sampled species.

FLORESTA, Curitiba, PR, v. 47, n. 4, p.543 - 552,out/dez. 2017.

Garcia, B. N. R. et al. 
The use pattern of the main species grown in homegardens was analyzed by the preference value index (PVI) to identify the usefulness and importance of each species for the farmer. It was calculated by adding the abundance (Abu\%) to the relative frequency (Fre\%) (SEMEDO; BARBOSA, 2007), following the expression:

$$
\mathrm{PVI} \%=\mathrm{Abu} \%+\mathrm{Fre} \%
$$

in which: Abu\% is the number of individuals of a species divided by the total number of plants of all species observed in each homegarden multiplied by 100; Fre\% is the number of gardens in which a particular species occurs divided by the total number of observed gardens and multiplied by 100 .

For data analysis, a database was constructed containing the information from the interviews and floristic inventory. Thereafter, we performed descriptive statistics, Independent Samples t Test, to compare the means between the two groups. The data were analyzed and charted in Excel for Windows ${ }^{\circledR}$ and by Statistical Package for the Social Sciences (SPSS 15.0®).

We used cluster analysis to check the floristic similarity of homegardens. Cluster analysis consists in a multivariate analysis technique that separates groups according to some classification criterion. Our decision was taken so that there is homogeneity within and heterogeneity between groups (CRUZ; REGAZZI, 1994). The variables considered in this analysis were: species richness, plant density and size of homegardens (VIEIRA et al., 2012). They were analyzed by the Statistical Package for the Social Sciences (SPSS 15.0®).

\section{RESULTS}

In the 30 homegardens, 2270 plants of 67 species, 53 genera and 28 botanical families were recorded. In relation to plant growth habit, $86 \%$ were tree and $14 \%$, shrub species. The most representative families in number of species were Arecaceae followed by the families Rutaceae, Myrtaceae, Annonaceae and Caesalpiniaceae. It indicates predominance of these families in the homegardens. The number of species per botanical family in homegardens of southern and northeastern farmers is shown in figure 1.

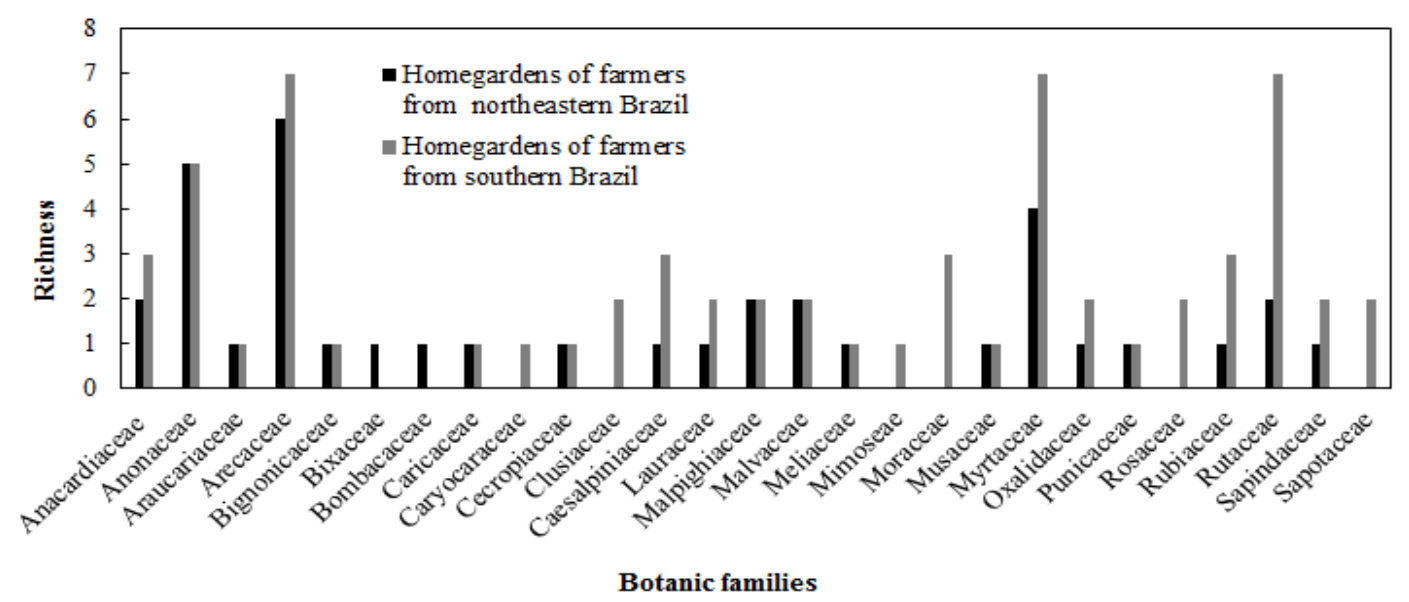

Figure 1. Richness of shrub and tree species per botanical family, registered in homegardens of farmers from northeastern and southern Brazil, in Santarém, Pará, Brazil.

Figura 1. Riqueza de espécies arbóreas e arbustivas por famílias botânicas, registradas em quintais agroflorestais de agricultores oriundos das regiões Nordeste e Sul do Brasil, em Santarém, Pará, Brasil.

The total number of species per homegarden ranged from 4 to 40 , and the average was 14 species per area. The origin of the farmers influenced in species richness (Figure 2). In homegardens of southern farmers (SUH), species richness was 64, and in homegardens of northeastern farmers (NEHs), 37. Thirty-two species are exclusive to the SUH and only 7 are exclusive to the NEHs. In the SUHs, the number of species per homegarden ranged from 5 to 40, while in NEHs, the range was 4 to 17.

FLOREST A, Curitiba, PR, v. 47, n. 4, p. 543 - 552, out/dez. 2017

Garvia, B. N. R. et al.

ISSN eletrônico 1982-4688

DOI: $10.5380 /$ rf.v47i4.48196 

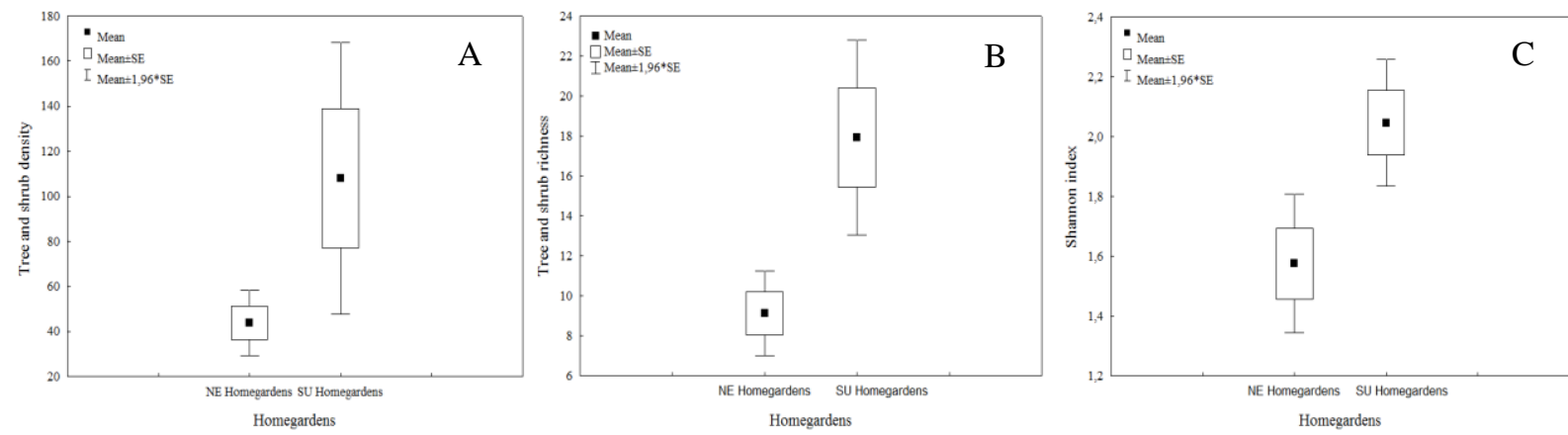

Figure 2. Significant differences (independent-samples t-test) among agroforestry homegardens of farmers from northeastern (NE) and southern (SU) Brazil, for Density (A), Richness (B), and Diversity index (C). $(\mathrm{n}=30)$.

Figura 2. Diferenças significativas (teste $t$ de amostras independentes) entre quintais agroflorestais de agricultores oriundos das regiões Nordeste (NE) e Sul (SU) do Brasil, para Densidade (A), Riqueza (B) e índice de Diversidade $(\mathrm{C})$. $(\mathrm{n}=30)$.

The results showed high species richness in some relatively small homegardens (about $100 \mathrm{~m}^{2}$ ); for example in $\mathrm{H} 23$, with 36 species. In larger homegardens $\left(10,200 \mathrm{~m}^{2}\right)$, the number of cultivated species was 40 , which was the maximum richness found. Regarding the number of plants, the best-represented botanical families were Musaceae with 683 (30.01\%), followed by Arecaceae with 676 (29.8\%), Malvaceae with 214 (9.4\%), and Rutaceae with 172 (7.6\%).

The species responsible for the high number of plants sampled for the family Musaceae were Musa spp. (Banana), Euterpe oleracea, Bactris gasipaes and Cocos nucifera L. of the family Arecaceae and Theobroma grandiflorum of Malvaceae. The Rutaceae and Lauraceae families with numerous species and varieties were equally important in these gardens as fruit suppliers, for being an element of the eating habits (Table 1).

Table 1. Tree and shrub species present in homegardens in Santarém, Pará, Brazil. Relative abundance (ABU), relative frequency (FR\%) and preference value index (PVI). FN: farmers from northeastern Brazil; and FS: farmers from southern Brazil. $(\mathrm{n}=30)$.

Tabela 1. Espécies arbóreas e arbustivas presentes em quintais agroflorestais em Santarém, Pará, Brasil. Abundância relativa (ABU), frequência relativa $(\mathrm{FR} \%)$ e índice de valor de preferência (PVI). FN: agricultores oriundos do Nordeste do Brasil; e FS: agricultores oriundos do Sul do Brasil. $(\mathrm{n}=30)$.

\begin{tabular}{|c|c|c|c|c|c|c|c|}
\hline Family & Scientific name & Common name & Presence & Origin & ABU\% & FR\% & PVI \\
\hline \multirow[t]{3}{*}{ Anacardiaceae } & Anacardium occidentale $\mathrm{L}$. & Cashew & FS & Exotic & 0.18 & 13.33 & 13.51 \\
\hline & Mangifera indica $\mathrm{L}$. & Mango & FN; FS & Exotic & 1.23 & 46.67 & 47.90 \\
\hline & Mangifera sp. & Mango Rose & FN & Exotic & 0.13 & 6.67 & 6.80 \\
\hline \multirow[t]{6}{*}{ Annonaceae } & Annona sp. & Araticum & FS & Exotic & 0.09 & 3.33 & 3.42 \\
\hline & Annona squamosa $\mathrm{L}$. & Sugar apple & FN; FS & Exotic & 0.88 & 23.33 & 24.21 \\
\hline & Rollinia mисоsa (Jacq.) Baill & Biriba & FN; FS & Native & 0.09 & 6.67 & 6.75 \\
\hline & Annona muricata $\mathrm{L}$. & Soursoup & FN; FS & Exotic & 1.23 & 33.33 & 34.57 \\
\hline & Spondias mombim L. & Taperebá & FS & Native & 0.13 & 6.67 & 6.80 \\
\hline & Spondias sp & Cajarana & FN; FS & Exotic & 0.53 & 30.00 & 30.53 \\
\hline Araucariaceae & Araucaria angustifolia (Bert.) Kuntze & Brazilian pine & FN; FS & Exotic & 0.44 & 10.00 & 10.44 \\
\hline \multirow[t]{8}{*}{ Arecaceae } & Oenocarpus bacaba Mart. & Turu palm & FN; FS & Native & 0.70 & 16.67 & 17.37 \\
\hline & Euterpe oleracea Martius & Açaí palm & FN; FS & Native & 10.48 & 50.00 & 60.48 \\
\hline & Mauritia flexuosa L.f & Moriche palm & FN & Native & 0.04 & 3.33 & 3.38 \\
\hline & Butia sp. (Mart.) Becc. & Butiá & FS & Exotic & 0.18 & 10.00 & 10.18 \\
\hline & Cocos nucifera $\mathrm{L}$. & Coconut & FN; FS & Exotic & 7.40 & 90.00 & 97.40 \\
\hline & NI & - & FS & - & 2.64 & 6.67 & 9.31 \\
\hline & Bactris gasipaes Kunth & Peach palm & FN; FS & Native & 8.24 & 66.67 & 74.90 \\
\hline & $\begin{array}{l}\text { Archontophoenix alexandrae (F. } \\
\text { Muell.) H. Wendl. \& Drude }\end{array}$ & Alexander palm & FN & Exotic & 0.04 & 3.33 & 3.38 \\
\hline Bignonicaceae & Tabebuia serratifolia (Vahl.) Nich & Yellow Ipé & FN; FS & Native & 0.31 & 10.00 & 10.31 \\
\hline
\end{tabular}




\begin{tabular}{|c|c|c|c|c|c|c|c|}
\hline Bixaceae & Bixa orellana $\mathrm{L}$. & Lipstick tree & FN & Native & 0.04 & 3.33 & 3.38 \\
\hline Bombacaceae & Ceiba pentandra (L.) Gaertn & Java kapok & $\mathrm{FN}$ & Native & 0.04 & 3.33 & 3.38 \\
\hline Calophyllaceae & Mammea americana $\mathrm{L}$. & Abricot & FS & Native & 0.09 & 3.33 & 3.42 \\
\hline Caricaceae & Carica papaya $\mathrm{L}$. & Papaya & FN; FS & Exotic & 3.92 & 56.67 & 60.59 \\
\hline Caryocaraceae & Caryocar villosum (Aubl.) Pers & Piquiá & FS & Native & 0.04 & 3.33 & 3.38 \\
\hline Cecropiaceae & Cecropia sp. & Yarumo & FN; FS & Native & 0.22 & 13.33 & 13.55 \\
\hline \multirow[t]{2}{*}{ Clusiaceae } & Garcinia mangostana $\mathrm{L}$ & Mangosteen & FS & Exotic & 0.04 & 3.33 & 3.38 \\
\hline & Rheedia brasiliensis Mart & Bakupari & FS & Native & 0.04 & 3.33 & 3.38 \\
\hline \multirow[t]{4}{*}{ Caesalpiniaceae } & Caesalpinia ferrea Mart et. Tul. & $\begin{array}{l}\text { Brazilian } \\
\text { ironwood }\end{array}$ & FN & Exotic & 0.04 & 3.33 & 3.38 \\
\hline & Caesalpinia echinata Lam. & Brazilwood & FS & Exotic & 0.04 & 3.33 & 3.38 \\
\hline & Tamarindus indica $\mathrm{L}$. & Tamarind & FS & Exotic & 0.09 & 6.67 & 6.75 \\
\hline & Copaifera reticulata Ducke & Copaíba & FS & Native & 0.13 & 3.33 & 3.47 \\
\hline \multirow[t]{2}{*}{ Lauraceae } & Persea americana Will. & Avocado & FN; FS & Exotic & 2.73 & 70.00 & 72.73 \\
\hline & Cinnamomum zeylanicum $\mathrm{L}$. & Cinnamon & FS & Exotic & 0.04 & 3.33 & 3.38 \\
\hline \multirow[t]{2}{*}{ Malpighiaceae } & Malpighia glabra L. & Barbados Cherry & FN; FS & Exotic & 2.82 & 56.67 & 59.49 \\
\hline & Byrsonima crassifolia (L.)H.B.K. & Golden spoon & FN; FS & Native & 0.35 & 23.33 & 23.69 \\
\hline \multirow[t]{2}{*}{ Malvaceae } & Theobroma cacao $\mathrm{L}$. & Cocoa & FN; FS & Native & 0.09 & 6.67 & 6.75 \\
\hline & $\begin{array}{l}\text { Theobroma grandiflorum (Willd. ex. } \\
\text { Spreng) Schum }\end{array}$ & Cupuassu & FN; FS & Native & 9.34 & 56.67 & 66.01 \\
\hline \multirow[t]{2}{*}{ Meliaceae } & Carapa guianensis Aublet & Andiroba & FS & Native & 0.04 & 3.33 & 3.38 \\
\hline & Swietenia macrophylla King. & Mahogany & FN & Native & 0.04 & 3.33 & 3.38 \\
\hline Mimoseae & Inga edulis Mart. & Ice-cream-bean & FS & Native & 0.13 & 10.00 & 10.13 \\
\hline \multirow[t]{3}{*}{ Moraceae } & Morus nigra $\mathrm{L}$. & Mulberry & FS & Exotic & 0.53 & 23.33 & 23.86 \\
\hline & Ficus carica $\mathrm{L}$. & Fig & FS & Exotic & 0.62 & 26.67 & 27.28 \\
\hline & Artocarpus heterophyllus Lam. & Jackfruit & FS & Exotic & 0.18 & 6.67 & 6.84 \\
\hline Musaceae & Musa spp. & Banana & FN; FS & Exotic & 30.09 & 60.00 & 90.09 \\
\hline \multirow[t]{4}{*}{ Myrtaceae } & Eugenia cumini L. & Plum & FS & Exotic & 0.35 & 13.33 & 13.69 \\
\hline & Psidium guianense Pers. & Brazilian guava & FS & Native & 0.09 & 6.67 & 6.75 \\
\hline & Eugenia guajava $\mathrm{L}$. & Guava & FN; FS & Exotic & 1.63 & 50.00 & 51.63 \\
\hline & Myrciaria cauliflora (Mart.) O. Berg & Brazilian Grape & FN; FS & Exotic & 0.53 & 23.33 & 23.86 \\
\hline \multirow[t]{2}{*}{ Oxalidaceae } & Averrhoa carambola $\mathrm{L}$. & Starfruit & FN; FS & Exotic & 0.26 & 16.67 & 16.93 \\
\hline & Averrhoa bilimbi $\mathrm{L}$. & Cucumber tree & FS & Exotic & 0.04 & 3.33 & 3.38 \\
\hline Punicaceae & Punica granatum $\mathrm{L}$. & Pomegranate & FN; FS & Exotic & 0.97 & 33.33 & 34.30 \\
\hline \multirow[t]{2}{*}{ Rosaceae } & Prunus avium $\mathrm{L}$. & Wild cherry & FN; FS & Exotic & 0.04 & 3.33 & 3.38 \\
\hline & Cydonia vulgaris Pers. & Quince & FS & Exotic & 0.04 & 3.33 & 3.38 \\
\hline \multirow[t]{3}{*}{ Rubiaceae } & Coffea arabica $\mathrm{L}$. & Coffee & FS & Exotic & 0.22 & 3.33 & 3.55 \\
\hline & Genipa americana $\mathrm{L}$. & Genipapo & FS & Native & 0.04 & 3.33 & 3.38 \\
\hline & Morinda citrifolia $\mathrm{L}$. & Indian mulberry & FN; FS & Exotic & 0.35 & 13.33 & 13.69 \\
\hline \multirow[t]{7}{*}{ Rutaceae } & Citrus sinensis (L.) Osbeck & Orange & FN; FS & Exotic & 4.98 & 73.33 & 78.31 \\
\hline & Citrus nobilis Lour. & Tangerina & FS & Exotic & 1.01 & 23.33 & 24.35 \\
\hline & $\begin{array}{l}\text { Citrus aurantifolia (Christm.) } \\
\text { Swingle }\end{array}$ & Key lime & FS & Exotic & 0.13 & 10.00 & 10.13 \\
\hline & Citrus limonia (L.) Osbeck & Lemandarin & FN; FS & Exotic & 1.06 & 50.00 & 51.06 \\
\hline & Citrus sp. & Limão doce & FS & Exotic & 0.09 & 3.33 & 3.42 \\
\hline & Citrus sp. & Lime & FS & Exotic & 0.22 & 6.67 & 6.89 \\
\hline & Citrus sp. & Mandarin-lime & FS & Exotic & 0.09 & 3.33 & 3.42 \\
\hline \multirow[t]{2}{*}{ Sapindaceae } & Talisia esculenta Radlik. & Pitomba & FN; FS & Native & 0.13 & 10.00 & 10.13 \\
\hline & Nephelium lappaceum $\mathrm{L}$. & Rambutan & FS & Exotic & 0.22 & 6.67 & 6.89 \\
\hline \multirow[t]{2}{*}{ Sapotaceae } & Pouteria caimito Radlk. & Abiu & FS & Native & 0.09 & 6.67 & 6.75 \\
\hline & Manilkara zapota (L.) P. van Royen & Sapodilla & FS & Exotic & 0.09 & 6.67 & 6.75 \\
\hline
\end{tabular}

FLORESTA, Curitiba, PR, v. 47, n. 4, p. 543 - 552, out/dez. 2017

Garvia, B. N. R. et al.

ISSN eletrônico 1982-4688

DOI: $10.5380 /$ rf.v47i4.48196 
Cocos nucifera (coconut) stood out as the most frequently found species in the homegardens. It is explained by the interest of farmers in the production of this fruit, mainly for consumption of coconut water, which is adipsous and a natural remedy, aside from being a species with commercial value and annual production.

Other most common species in the gardens were orange (Citrus sinensis), avocado (Persea americana), peach palm (Bactris gasipae), banana (Musa spp), acerola (Malpighia glabra), papaya (Carica papaya), and cupuassu (Theobroma grandiflorum). Coconut had the highest preference value index (97.37), followed by banana, orange, peach palm and avocado, which confirms the preference of farmers for species of fruit as well as commercial value.

Among the species found, 64\% $(\mathrm{N}=45)$ were exotic, 34\% $(\mathrm{N}=24)$ were native to the Amazon region, and $1 \%(\mathrm{~N}=1)$ had no identified origin. Regarding the diversity of species, the Shannon-Wiener ( $\left.\mathrm{H}^{\prime}\right)$ index ranged from 0.57 (for H03) to 2.80 (for H25), which indicates a great difference in the homegarden diversity (Figure 2; Table 2). Diversity index was higher in the southerners' homegardens.

Table 2. Density (D), Richness (S), Diversity index (H') and Evenness index (E) in agroforestry homegardens in Santarém, Pará, Brazil $(\mathrm{n}=30)$.

Tabela 2. Densidade (D), Riqueza (S), índice de Diversidade (H') e índice de equabilidade (E) em quintais agroflorestais em Santarém, Pará, Brasil. $(\mathrm{n}=30)$.

\begin{tabular}{cccccccccccc}
\hline Origin & $\begin{array}{c}\text { Home- } \\
\text { garden }\end{array}$ & $\mathbf{D}$ & $\mathbf{S}$ & $\mathbf{H}^{\prime}$ & $\mathbf{E}$ & Origin & $\begin{array}{c}\text { Home- } \\
\text { garden }\end{array}$ & $\mathbf{D}$ & $\mathbf{S}$ & $\mathbf{H}^{\prime}$ & $\mathbf{E}$ \\
\hline $\mathbf{N E}$ & $\mathrm{H} 01$ & 20 & 6 & 1.54 & 0.86 & $\mathbf{S U}$ & $\mathrm{H} 16$ & 164 & 20 & 1.88 & 0.63 \\
$\mathbf{N E}$ & $\mathrm{H} 02$ & 20 & 7 & 1.37 & 0.70 & $\mathbf{S U}$ & $\mathrm{H} 17$ & 441 & 40 & 1.83 & 0.50 \\
$\mathbf{N E}$ & $\mathrm{H} 03$ & 27 & 4 & 0.57 & 0.41 & $\mathbf{S U}$ & $\mathrm{H} 18$ & 136 & 21 & 2.18 & 0.72 \\
$\mathbf{N E}$ & $\mathrm{H} 04$ & 80 & 11 & 2.21 & 0.92 & $\mathbf{S U}$ & $\mathrm{H} 19$ & 64 & 17 & 2.20 & 0.78 \\
$\mathbf{N E}$ & $\mathrm{H} 05$ & 110 & 16 & 1.81 & 0.65 & $\mathbf{S U}$ & $\mathrm{H} 20$ & 35 & 11 & 1.95 & 0.81 \\
$\mathbf{N E}$ & $\mathrm{H} 06$ & 70 & 13 & 2.04 & 0.80 & $\mathbf{S U}$ & $\mathrm{H} 21$ & 75 & 15 & 2.36 & 0.87 \\
$\mathbf{N E}$ & $\mathrm{H} 07$ & 77 & 17 & 1.83 & 0.65 & $\mathbf{S U}$ & $\mathrm{H} 22$ & 77 & 11 & 1.29 & 0.54 \\
$\mathbf{N E}$ & $\mathrm{H} 08$ & 42 & 7 & 1.44 & 0.74 & $\mathbf{S U}$ & $\mathrm{H} 23$ & 314 & 36 & 2.34 & 0.65 \\
$\mathbf{N E}$ & $\mathrm{H} 09$ & 60 & 12 & 2.04 & 0.82 & $\mathbf{S U}$ & $\mathrm{H} 24$ & 70 & 16 & 2.14 & 0.77 \\
$\mathbf{N E}$ & $\mathrm{H} 10$ & 27 & 11 & 1.97 & 0.82 & $\mathbf{S U}$ & $\mathrm{H} 25$ & 91 & 26 & 2.80 & 0.86 \\
$\mathbf{N E}$ & $\mathrm{H} 11$ & 20 & 6 & 1.58 & 0.88 & $\mathbf{S U}$ & $\mathrm{H} 26$ & 12 & 9 & 2.02 & 0.92 \\
$\mathbf{N E}$ & $\mathrm{H} 12$ & 29 & 6 & 0.93 & 0.52 & $\mathbf{S U}$ & $\mathrm{H} 27$ & 56 & 16 & 2.21 & 0.80 \\
$\mathbf{N E}$ & $\mathrm{H} 13$ & 24 & 6 & 1.39 & 0.78 & $\mathbf{S U}$ & $\mathrm{H} 28$ & 48 & 14 & 2.16 & 0.82 \\
$\mathbf{N E}$ & $\mathrm{H} 14$ & 37 & 11 & 1.84 & 0.77 & $\mathbf{S U}$ & $\mathrm{H} 29$ & 20 & 12 & 2.25 & 0.91 \\
$\mathbf{N E}$ & $\mathrm{H} 15$ & 15 & 4 & 1.08 & 0.78 & $\mathbf{S U}$ & $\mathrm{H} 30$ & 17 & 5 & 1.09 & 0.68 \\
\hline
\end{tabular}

The homegardens with greatest diversity were H25, H21 and H23 with a Shannon index of 2.80; 2.36 and 2.34, respectively. Those with lowest diversity were $\mathrm{H} 3, \mathrm{H} 12$ and $\mathrm{H} 15$, with $0.57,0.93$ and 1.08 . The highest diversity indices were found in SUHs. Thus, the average index for the NEHs was 1.58, while SUHs obtained 2.05. The diversity in the homegardens can be considered medium, with an average index of 1.8. The evenness values ranged from 0.41 ( $\mathrm{H} 03$ ) to 0.92 ( $\mathrm{H} 04$ and $\mathrm{H} 26$ ). In $66 \%$ of the homegardens, the evenness index was higher than 0.7.

There was no statistical difference to evenness indices. In the homegardens $\mathrm{H} 03, \mathrm{H} 17$ and $\mathrm{H} 12$, in which açaí palm (Euterpe oleracea) and banana are predominant over other species, it was $0.41,0.50$ and 0.52 , respectively. The maximum values were found in the gardens $\mathrm{H} 04, \mathrm{H} 26, \mathrm{H} 29$, and $\mathrm{H} 11(0.92 ; 0.92 ; 0.91$, and 0.88 , respectively).

The floristic similarity dendrogram (Figure 3) allowed the formation of three plant density groups of homegardens: group A, consisting of 17 homegardens with low plant density $(17-60)$; group B, consisting of 11 gardens with intermediate density (64 - 164); and group C, containing few homegardens with high density (314 - 441). 


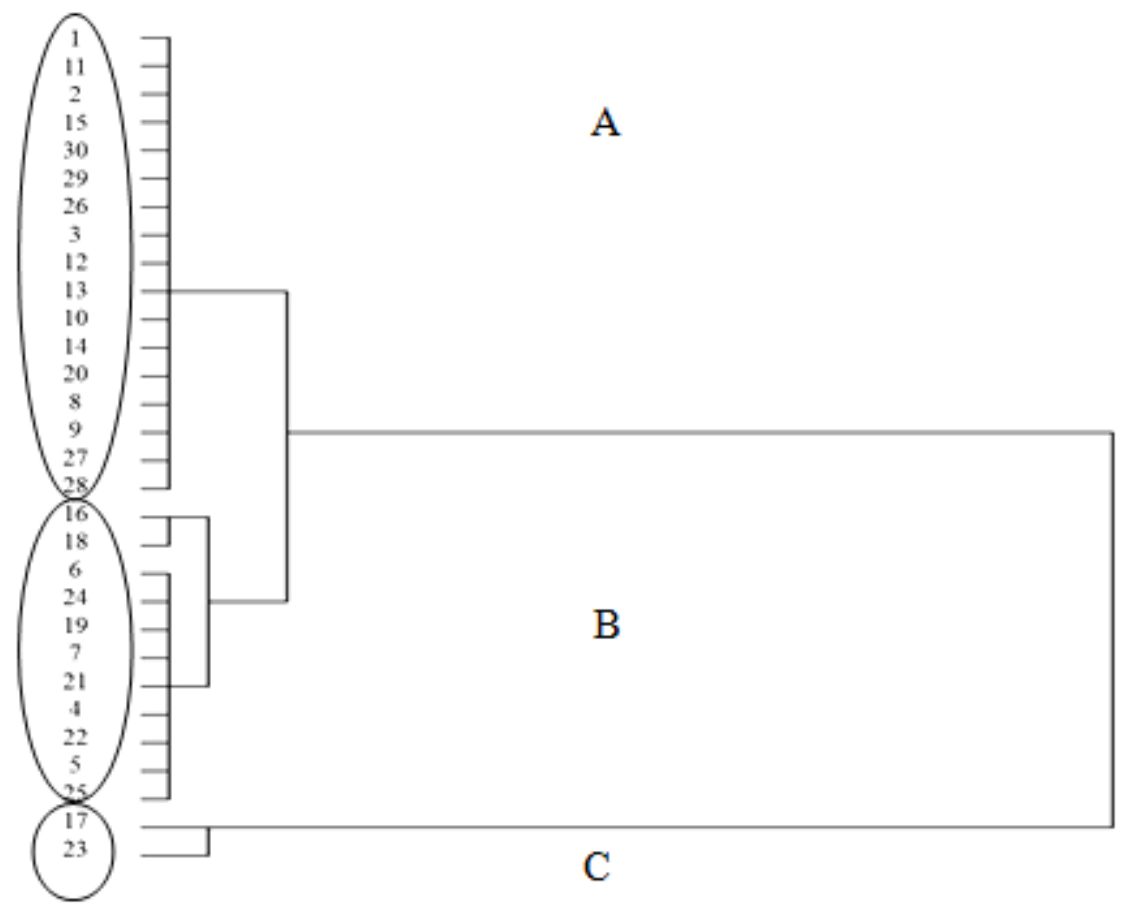

Figure 3. Dendrogram of floristic similarity of agroforestry homegardens in Santarém, Eastern Amazon, Brazil. A, $\mathrm{B}, \mathrm{C}$ : agroforestry homegardens groups formed from dendrogram.

Figura 3. Dendrograma de similaridade florística de quintais agroflorestais em Santarém, Pará, Brasil. A, B, C: grupos de quintais agroflorestais formados a partir do dendrograma.

\section{DISCUSSION}

The botanical families of plant food species that produce caloric or protein-rich fruits - and are tasty as well - were represented the best (TROTTA et al., 2012). It was represented as well by the families that stood out in this study. The use of species of the family Arecaceae is emphasized in homegarden studies, due to their commercial value that may generate income and be used for self-supply of local populations (TROTTA et al., 2012).

In a study on the floristic composition of homegardens in Amazonia, Brizidio and Nunes (2011) identified 141 plant species, distributed in 60 botanical families in 30 yards, a higher richness than the one in this study, which demonstrates that this variable depends on environmental conditions. According to Rosa et al. (2007), culture has a strong influence on the floristic composition of homegardens in Amazonia, since knowledge on crop cultivation is being passed down from one generation to the next.

Regarding the influence of species richness on homegardens, the cultural aspect leads to differences in the focus of the management of these systems; consequently, farmers that are more interested tend to introduce more species. They do so by exchanging seedlings and seeds with each other, as observed during the survey. In this sense, Vieira et al. (2012) recall that the option of cultivating a great richness of species in the homegarden is the owners' personal choice.

Duque Brasil et al. (2011) and Vieira et al. (2012) also found fruit trees such as banana and coconut as the most abundant in different studies on homegardens of family farmers. The abundance of banana plants can be explained by the ease of management and marketing of these fruits. Thus, the abundance of acai palm plants is justified since a beverage of this fruit is highly demanded in the region of the study. It also supplies subsistence and market consumption.

Peach palm belongs to the same family and its high occurrence is given by the value of the fruit - highly appreciated in the community. A major part of the production of this crop in the region of Santarem is supplied from homegardens. The species cupuassu is particularly emphasized in studies of these land use systems, as in those of Rosa et al. (2007) and Vieira et al. (2012). In spite of reports on the occurrence of witch broom disease

FLORESTA, Curitiba, PR, v. 47, n. 4, p. 543 - 552, out/dez. 2017

Garvia, B. N. R. et al.

ISSN eletrônico 1982-4688

DOI: $10.5380 /$ rf.v47i4.48196 
(Moniliophthora perniciosa), its cultivation is still very important, owing to the cultural and economic context (great marketing potential) of the region.

The high frequency of coconut cultivation is a result of marketing and subsistence consumption, but also of cultural reasons (VIEIRA et al., 2007). Coconut is sold to vendors of the proper community who are often responsible for harvesting the palm fruit themselves.

In a survey conducted by Vieira et al. (2007) in areas of family farmers of Igarapé-Açu, Pará, Brazil, the species of cupuassu, cashew, açaí palm, peach palm and coconut were the most frequent in the commercial agroforestry systems. The frequency of these species in homegardens may be due to the relative commercial value the fruits have on local market, and to the readily available domesticated varieties with rapid fruit production. Also, their establishment is an inherited cultural practice, closely associated with the ease of management of these species.

In homegardens in Bonito, Pará, Brazil, Vieira et al. (2012) indicated coconut as the species with highest PVI (109.43). According to these authors, the appreciation can be explained by the fact that fruits of these species are part of the diet, as well as by their aggregated value.

These results suggest that the preference for fruit species outweighed the importance of the origin of species, giving priority to dietary habits and subsistence consumption. Cultural and social aspects were decisive factors for the farmers. Also, the management of the preferred species was "balanced", no high inputs required.

Regarding the diversity of homegardens in Boa Vista, Roraima, Brazil, Semedo and Barbosa (2007) found mean values close to one. The diversification in these gardens was considered low - lower than in homegardens in Bonito, Pará, Brazil (Vieira et al., 2012). An average diversity index was classified as high (2.21) and relatively high (3.54) in urban homegardens in Sao Paulo in a study of Trotta et al. (2012).

The evenness index indicated low dominance of species, showing there is a better distribution of plants within species and reducing the ecological dominance of species that stood out as the most abundant. These results are similar to those presented in studies of ecology of agroforestry systems in the Amazon region by Vieira et al. (2012) - who reported mean evenness values of 0.8.

\section{CONCLUSION}

- The most representative families in terms of number of species were Arecaceae, Rutaceae, Myrtaceae, Anacardiaceae and Annonaceae.

- The floristic composition of homegardens showed coconut as the most common and also species and with the highest Preference Value Index, which reveals the importance of this species for family farmers.

- The homegardens have moderate diversity and medium evenness indices, regardless the predominance of species such as banana and açaí.

- The origin of the farmers did not influence the similarity between homegardens, but influenced vegetal species richness, density and diversity, which were higher in the southerners' homegardens.

\section{ACKNOWLEDGEMENTS}

We thank the farmers for the warmth and friendliness with which they welcomed us to their properties, and the Higher Education Personnel Improvement Coordination (CAPES), for a graduate scholarship.

\section{REFERENCES}

AMOROZO, M. C. M. Os quintais: funções, importância e futuro. In: Guarim Neto, G.; Carniello, M.A. Quintais Mato-grossenses: espaços de conservação e reprodução de saberes. Cáceres: Unemat, 2008. p. 15-27.

BRIZIDIO, A. K.; NUNES, R. O. 2011. Composição florística dos quintais nos Bairros Floresta e Texeirão na cidade de Cacoal, Rondônia. Revista Facimed, v. 2, n. 2, p. 195-210.

COSTA, R. B.; ARRUDA, E. J.; OLIVEIRA, L. C. S. Sistemas agrossilvipastoris como alternativa sustentável para a agricultura familiar. Interações, v. 3, p. 25-32, 2002.

COSTANTIN, A. M.; VIEIRA, A. R. R. Quintais Agroflorestais na visão dos Agricultores de Imaruí-Sc. Revista Brasileira de Agroecologia, v. 5, p. 303-305, 2010. 
CRUZ, C. D.; REGAZZI, A. J. Divergência genética. In: C.D. Cruz, A.J. Regazzi (Ed). Métodos biométricos aplicados ao melhoramento genético. Viçosa: UFV, 1994. p. 287-323.

DUQUE-BRASIL, R.; SOLDATI, G. T.; ESPIRITO-SANTO, M. M.; REZENDE, M. Q.; D’ÂNGELO-NETO, S.; COELHO, F. M. G. 2011. Composição, uso e conservação de espécies arbóreas em quintais de agricultores familiares na região da mata seca norte-mineira, Brasil. Sitientibus série Ciências Biológicas, v. 11, n. 2, p. 287297, 2011.

INSTITUTO DE DESENVOLVIMENTO ECONÔMICO, SOCIAL E AMBIENTAL DO ESTADO DO PARÁ (IDESP). Estatística municipal: Santarém. (www.idesp.pa.gov.br/paginas/produtos/EstatisticaMunicipal/pdf/ Santarem.pdf). Accessed in: Sept. 10, 2013.

MAGURRAN, A. E. Ecological diversity and its measurement. Cambridge: British Library, 179 p., 1988.

PEREIRA, K. J. C.; REIS, R. S.; VEASEY, E. A. Saber Tradicional e Manejo de Paisagens Agroflorestais: O Caso dos Quintais de Terra-Firme da Reserva de Desenvolvimento Sustentável Amanã, Amazonas. Revista Brasileira Agroecologia, v. 2, n. 1, p. 562-565, 2007.

RONDON NETO, R. M.; BYCZKOVSKI, A.; WINNICKI, J. A.; SIMÃO, S. M. M.; PASQUALOTTO, T. C. Os quintais agroflorestais do assentamento rural Rio da Areia, município de Teixeira Soares, PR. Cerne, v. 10, n. 1, p. 125-135, 2004.

ROSA, L. S.; SILVEIRA, E. L.; SANTOS, M. M.; MODESTO, R. S.; PEROTE, J. R. S.; VIEIRA, T. A. Os quintais agroflorestais em áreas de agricultores familiares no município de Bragança- PA: composição florística, uso de espécies e divisão de trabalho familiar. Revista Brasileira de Agroecologia, v. 2, n. 2, p. 337-341, 2007.

SEMEDO, R. J. C. G.; BARBOSA, R. I. 2007. Árvores frutíferas nos quintais urbanos de Boa Vista, Roraima, Amazônia brasileira. Acta Amazonica, v. 37, p. 497-504.

TROTTA, J.; MESSIAS, P. A.; PIRES, A. H. C.; HAYASHIDA, C. T.; CAMARGO, C.; FUTEMMA, C. Análise do conhecimento e uso popular de plantas de quintais urbanos no Estado de São Paulo, Brasil. Revista de Estudos Ambientais, v. 14, n. 3, p. 17-34, 2012.

VIEIRA, T. A.; ROSA, L. S.; VASCONCELOS, P. C. S.; SANTOS, M. M.; MODESTO, R. S. Sistemas agroflorestais em áreas de agricultores familiares em Igarapé-Açu, Pará: caracterização florística, implantação e manejo. Acta Amazonica, v. 37, n. 4, p. 549-558, 2007.

VIEIRA, T. A.; ROSA, L. S.; SANTOS, M. M. L. S. Agrobiodiversidade de quintais agroflorestais no município de Bonito, Pará. Revista de Ciências Agrárias, v. 55, p. 159-166, 2012.

VIEIRA, T. A.; ROSA, L. S.; SANTOS, M. M. L. S. Condições socioeconômicas para o manejo de quintais agroflorestais em Bonito, Pará. Revista Brasileira de Ciências Agrária, v. 8, n. 3, p. 458-463, 2013.

FLOREST A, Curitiba, PR, v. 47, n. 4, p. 543 - 552, out/dez. 2017

Garvia, B. N. R. et al.

ISSN eletrônico 1982-4688

DOI: $10.5380 /$ rf.v47i4.48196 
FLORESTA, Curitiba, PR, v. 47, n. 4, p.543 - 552,out/dez. 2017. Garcia, B. N. R. et al. 